\title{
Kábítószer-probléma Magyarországon az elmúlt 10 évben
}

Drug problems in Hungary in the last 10 years

\author{
Szerző: $\quad$ Nyírády Adrienn $\square$ \\ Nemzeti Egészségfejlesztési Intézet
}

Kulcsszavak: Nemzeti Drog Fókuszpont; EMCDDA; kábítószer; drog; jelentés

Keywords: Hungarian National Focal Point; EMCDDA; narcotic; drug; report

Az elmúlt tíz évben komoly erőfeszítések történtek a kábítószerügyi adatgyűjtés kiépítése és a magyarországi kábítószerhelyzetet bemutató, nemzetközi gyakorlatnak megfelelő elemzések összeállítása érdekében. A Nemzeti Drog Fókuszpont 2004 óta végzi tevékenységét a kábítószer-problémára adott hatékony válaszlépések tudományos eredményeken alapuló, hiteles támogatásával és a nemzetközi adatszolgáltatási kötelezettség magas színvonalú teljesítésével. A kábítószer-helyzet Magyarországon 2004-2014 című kötet az elmúlt tíz évet áttekintve a kábítószer-probléma alakulását követi nyomon, törekedve a trendek és a jelenlegi helyzetet megalapozó főbb változások bemutatására. Számot ad a kábítószer-probléma alakulásával és a válaszlépésekkel kapcsolatos legfontosabb fejleményekről, így a jogszabályi változásokról; a szerhasználati mintázatokban bekövetkezett változásokról és a kezelésbe kerülőkről; a fertőző betegségek és a halálozás alakulásáról; valamint a kábítószer-piaci lefoglalási és bűnözési statisztikákról. 